\title{
Constraints and Suggestions of Certified Organic Farmers in Practicing Organic Farming in Western Zone of Tamil Nadu, India
}

\author{
P. Sivaraj ${ }^{1}$, H. Philip ${ }^{2}$, M. Chinnadurai ${ }^{1}$, M. Asokhan ${ }^{1}$ and K. Sathyamoorthi ${ }^{3}$ \\ ${ }^{1}$ Centre for Agriculture and Rural Development Studies, TNAU, Coimbatore, 641 003, India \\ ${ }^{2}$ Directorate of Extension Education, TNAU, Coimbatore, 641003 , India \\ ${ }^{3}$ Directorate of Research, TNAU, Coimbatore, 641 003, India \\ *Corresponding author:
}

\begin{tabular}{|c|c|}
\hline & A B S T R A C T \\
\hline Keywords & \multirow{4}{*}{$\begin{array}{l}\text { The study was conducted among certified organic farmers of Tamil Nadu. A sample } \\
\text { size of } 180 \text { organic farmers was selected from the districts of Coimbatore, Erode and } \\
\text { Tiruppur districts of Tamil Nadu. Data was collected through personnel interview } \\
\text { method with help of semi structured interview schedule. Simple percentage analysis } \\
\text { and simple ranking method are used for the study. Findings revealed that majority of } \\
\text { the certified organic farmers faced constraints were inadequate availability of organic } \\
\text { inputs in time }(68.89 \%) \text {, scarcity of irrigation water ( } 64.45 \%) \text {, lack of quality training } \\
\text { on organic farming practices }(60.00 \%) \text {, limited experts in preparation of organic } \\
\text { inputs }(58.89 \%) \text { etc. Meaningful suggestions were encountered from the certified } \\
\text { organic farmers for enhancing adoption of organic farming in the study area. }\end{array}$} \\
\hline $\begin{array}{l}\text { Constraints, Organic } \\
\text { farming, Organic } \\
\text { inputs, Suggestions } \\
\text { and Trainings. }\end{array}$ & \\
\hline Article Info & \\
\hline $\begin{array}{l}\text { Accepted: } \\
\text { 20 February } 2017 \\
\text { Available Online: } \\
10 \text { March } 2017\end{array}$ & \\
\hline
\end{tabular}

\section{Introduction}

Agriculture is the most important livelihood strategy in India, with two thirds of the county's workforce depending on farming. Organic farming can be seen as an approach to agriculture where the aim is to create integrated, environmentally and economically sustainable agricultural production systems. Conventional farming is based on the use of high yielding varieties of seeds, chemical fertilizer, irrigation water, pesticides etc. Whereas organic farming tends to satisfy the ever growing demand for food grains not only to fulfill the problem of food security but also to earn foreign exchange at the cost of environmental quality which cannot be sustainable in future. Organic farming is both a philosophy and a system of agriculture. The objects of environment, social and economic sustainability at the heart of organic farming and are among the major factors determining the acceptability or otherwise of specific production practices (Stockdale et al., 2001).

Organic farming improves the soil's biological properties such as supply and retention of soil nutrients and promotes favourable chemical reactions, production of clean foods, improves the soil physical properties such as granulation and good tilth, good aeration and easy root penetration, improves water holding capacity in sustaining production system which is largely dependent on on-farm resources (Thiripurasundari et al., 2015). India is bestowed with lot of potential 
to produce all organic products due to its suitable agro-climatic factors in several parts of the country; the inherited tradition of organic farming is an added advantage (APEDA, 2010).

Organic farming is a productive system in which environment is preserved, farmers and workers have fair access to the means of food production while receiving a fair return for their labour and consumers have their food at fair prices (Jaganathan et al., 2012). In India, still farmers face several constraints in practicing organic farming like more cost and risk involvement in getting organic manure (vermicompost, oil cakes etc), transportation of green manure, lack of ready packages for growing rice organically and lack of knowledge on crop rotation, water management and a few complete organic farming practices were the major constraints faced by a 60.00 per cent of the small farmers to practice organic farming (Ranganatha et al., 2001). Based on this background the study was conducted among 180 certified organic farmers in Coimbatore, Erode and Tiruppur districts of Tamil Nadu.

\section{Materials and Methods}

\section{Selection of the study area}

The Western zone of Tamil Nadu viz. Coimbatore, Erode and Tiruppur districts were selected purposively, as maximum numbers of organic farmers have registered under the category of individual certified organic farmers. Practising organic farming in different crops like coconut, banana, pulses and turmeric from the study area.

\section{Selection of respondents}

A total sample size of 180 certified organic farmers are selected for the study. A sample size of 60 organic farmers was considered for the study in each of the districts such as Coimbatore, Erode and Tiruppur respectively. In each district, three blocks were selected and in each block 20 certified organic farmers were selected through Purposive random sampling method (Table 1).

\section{Data collection and analysis}

A well structured and pre-tested interview schedule was used for data collection. Keeping in view, the objectives and the variables under study, a comprehensive semi structured interview schedule covering all aspects of organic farming practices was prepared. The items included in the interview schedule were structured questions and objective type questions which were suitable to all categories of organic farmers. The most relevant, unambiguous and practical questions were included in the schedule duly avoiding irrelevant items. Each of the selected certified organic farmers was contact personally and interviewed. The data collected were subjected to statistical analysis to get inferences.

Percentage analysis was used in descriptive analysis for making simple comparisons. For calculating percentage, the frequency of the particular cell was multiplied by 100 and divided by the total number of respondents pertaining to particular cell. Percentage was corrected to two decimal places and finally ranked constraints faced by the organic farmers (20 numbers of constraints) and their suggestions to enhance adopting organic farming in study area (16 numbers of suggestions) according to percentage analysis.

\section{Results and Discussion}

In recent days organic farmers facing lot of problems in their farming, which may be climatic aberration, inadequate farm inputs, low market price for their produce and their situational conditions are restricting them to 
take up any adjustments in their farming due to lack of irrigation water facility. With this background efforts were made to know the constraints experienced by organic farmers and drawn fruitful suggestions were to overcome their problems.

\section{Constraints faced by organic farmers in practicing organic farming}

Inadequate availability of organic inputs in time $(68.89 \%)$ was identified as the first major constraint by the certified organic farmers based on the rank (Table 2). The reason might be due to the fact that in inorganic farming every input was available to them as readymade nature, whereas in organic farming, preparation of organic inputs and use of every practice was found to be tedious and risky. The certified organic farmers used various on farm resources and carried out organic farming practices in an eco-friendly way. Scarcity of irrigation water $(64.45 \%)$ was identified as the second major constraint by the certified organic farmers based on the rank, Most of the farmers felt that there were no storage structures for irrigation water. Most of the storage ponds were converted as residential plots and that too with buildings and other infrastructure. Hence, certified organic farmers found it very difficult to invest on the modern irrigation structure. They are also not aware of the Government schemes available in case of micro irrigation.

Lack of quality training on organic farming practices $(60.00 \%)$ was identified as the third major constraint by the certified organic farmers based on the rank, Lack of proper training at gross root level might be due to that the certified organic farmers encountered difficulties in the process of conversion due to lack of understanding, lack of knowledge and lack of readily available information about conversion process. Limited experts in preparation of organic inputs (panchakavaya, jeevamirta, more karaisal etc.) 58.89 per cent was identified as the fourth major constraint by the certified organic farmers based on the rank. Encourage and provide more training on organic input preparation for organic farmers.

Lack of technical guidance on organic farming $(57.23 \%)$ was identified as the fifth major constraint by the certified organic farmers based on the rank. The probable reason might be due to some of the respondents in study area had minimum educational status ranging from primary to secondary. Bulky nature of organic inputs $(56.12 \%)$ was identified as the sixth major constraint by the certified organic farmers based on the rank. Organic inputs like compost, vermi compost, green manure and green leaf manures are bulk in nature. So, organic farmers are facing some difficulties in handle organic inputs in farm level, lack of transport facility,

Non-availability of readymade organic inputs formulation (54.45\%) was identified as the seventh major constraint by the certified organic farmers based on the rank. The reason behind these organic inputs qualities are instability and changing nature. Hence, naturally it takes some more time to produce quality and standard inputs, wherein the desired benefits would have been understood by the organic farmers. Lack of control measures for pest and diseases $(51.67 \%)$ was identified as the eighth major constraint by the certified organic farmers based on the rank. This might be due to the fact that high prevalence of pests and diseases and higher incidence of weeds, which in turn drastically reduces the yield. The organic practices act only as pest repellent and not as pest control after the incidence of attack. Less number of technologies in organic farming practices (recommended by SAU/ Research stations) $(50.00 \%)$ was identified as the ninth major 
constraint by the certified organic farmers based on the rank. There is no separate package of practice for each and every crop to grow organically and no systematized package of practices is available for organic farming. Transfer of technology is undertaken, when package of practices recommended are tested and verified both in research stations and farmers fields. Some of the organic methods and inputs are yet to be validated by the scientists. Hence, transfer of technology mechanism has been cited as one of the major constraints.

Insufficient premium price for organic produce $(48.89 \%)$ was identified as the tenth major constraint by the certified organic farmers based on the rank. Lack of government support for marketing organic produce and lack of premium price in organic products were identified as the eleventh and twelfth problem. Even when the crops were grown organically, their products were sold in common market and it does not fetch any higher return. Hence, the government has to support certified organic farmers by establishing separate marketing channels for organic products. Similar results were also reported by Muttalageri and Mokshapathy (2015). High cost and non-availability of labour $(47.78 \%)$ was identified as the eleventh major constraint by the certified organic farmers based on the rank. The reason for non-availability of farm labour and high labour wage rate might be due to the migration of rural people to urban areas.

Insubstantial research programmes on organic farming (45.56\%) was identified as the twelfth major constraint by the certified organic farmers based on the rank. The reason might be due to recommended package of organic farming practices were not tested and validated by the scientists. Some of the organic methods and inputs are yet to be validated by the scientists. Cumbersome process and time period required for obtaining organic certification (44.45\%) was identified as the thirteenth major constraint by the certified organic farmers based on the rank. Access to certification, cost involved therein and a time lag of three years (conversion stage) which made the certified organic farmers to feel like complicated certification procedure. Besides, the cost of certification, a major component of which is the periodical inspections carried out by the certifying agencies, which had freedom to fix the timings, type and number of such inspections appeared to be burdensome for the certified organic farmers.

Insufficient marketing channels for organic produce $(43.34 \%)$ were identified as the fourteenth major constraint by the certified organic farmers based on the rank. Compared to conventional farming produce, organic farming produce were good quality and long time self life. Limited marketing channels only for organic produce in current situation for the betterment of the organic farmers need more special market zone for organic marketing. Non-availability of traditional seeds $(41.12 \%)$ was identified as the fifteenth major constraint by the certified organic farmers based on the rank. Due to the impact of green revolution the farmers cultivated hybrids to get higher yield and to reduce the incidence of pests and diseases which in turn reduced the cultivation of traditional varieties drastically year by year.

Lack of awareness programmes on organic farming in the media $(40.00 \%)$ was identified as the sixteenth major constraint by the certified organic farmers based on the rank. Even though the information dissemination on organic farming are communicated through ICT tools like televisions, mobile phones, computers are used in enhancing awareness level on organic farming. 
Table.1 Selected blocks and respondents in Coimbatore, Erode and Tiruppur Districts of Tamil Nadu

\begin{tabular}{|c|c|c|c|c|}
\hline S. No. & Name of the Districts & $\begin{array}{l}\text { Name of the } \\
\text { block }\end{array}$ & $\begin{array}{c}\text { Number of } \\
\text { selected farmers } \\
\text { from selected } \\
\text { blocks }\end{array}$ & $\begin{array}{c}\text { Number of } \\
\text { farmers from } \\
\text { selected districts }\end{array}$ \\
\hline \multirow{3}{*}{1.} & \multirow{3}{*}{ Coimbatore } & Anamalai & 20 & \multirow{3}{*}{60} \\
\hline & & Pollachi & 20 & \\
\hline & & Thondamuthur & 20 & \\
\hline \multirow{3}{*}{2.} & \multirow{3}{*}{ Erode } & Erode & 20 & \multirow{3}{*}{60} \\
\hline & & Gobichettipalam & 20 & \\
\hline & & Sathyamangalam & 20 & \\
\hline \multirow{3}{*}{3.} & \multirow{3}{*}{ Tiruppur } & Tiruppur & 20 & \multirow{3}{*}{60} \\
\hline & & Palladam & 20 & \\
\hline & & Udumalpet & 20 & \\
\hline \multicolumn{4}{|c|}{ Total } & 180 \\
\hline
\end{tabular}

Table.2 Constraints encountered by certified organic farmers in adoption of organic farming practices

\begin{tabular}{|c|l|c|c|c|}
\hline S. No. & \multicolumn{1}{|c|}{ Constraints } & Number* & Per cent & Rank \\
\hline 1. & Inadequate availability of organic inputs in time & 124 & 68.89 & I \\
\hline 2. & Bulky nature of organic inputs & 101 & 56.12 & VI \\
\hline 3. & Inadequate transport facilities & 54 & 30.00 & XX \\
\hline 4. & Lack of technical guidance on organic farming & 103 & 57.23 & V \\
\hline 5. & Scarcity of irrigation water & 93 & 51.67 & VIII \\
\hline 6. & Lack of control measures for pest and diseases & 88 & 48.89 & X \\
\hline 7. & Insufficient premium price for organic produce & 86 & 47.78 & XI \\
\hline 8. & High cost and non-availability of labour & 80 & 44.45 & XIII \\
\hline 9. & $\begin{array}{l}\text { Cumbersome process and time period required for } \\
\text { obtaining organic certification }\end{array}$ & 74 & 41.12 & XV \\
\hline 10. & Non-availability of traditional seeds & 82 & 45.56 & XII \\
\hline 11. & Insubstantial research programmes on organic farming & 33.34 & XIX \\
\hline 12. & Complicated methods for production of organic inputs & 60 & 60.00 & III \\
\hline 13. & Lack of quality training on organic farming practices & 108 & 40.00 & XVI \\
\hline 14. & $\begin{array}{l}\text { Lack of awareness programmes on organic farming in the } \\
\text { media }\end{array}$ & 72 & & \\
\hline 15. & Insufficient marketing channels for organic produce & 78 & 43.34 & XIV \\
\hline 16. & High risk and uncertainty of return & 69 & 38.34 & XVII \\
\hline 17. & $\begin{array}{l}\text { Less number of technologies in organic farming practices } \\
\text { (recommended by SAU/ Research stations) }\end{array}$ & 90 & 50.00 & IX \\
\hline 18. & No labeling / Standards for organic inputs & 66 & 36.67 & XVIII \\
\hline 19. & $\begin{array}{l}\text { Non-availability of readymade organic inputs } \\
\text { formulation }\end{array}$ & 98 & 54.45 & VII \\
\hline 20. & Limited experts in preparation of organic inputs & 106 & 58.89 & IV \\
\hline
\end{tabular}

* Multiple responses 
Table.3 Suggestions for enhancing adoption of organic farming practices

\begin{tabular}{|c|c|c|c|c|}
\hline \multicolumn{5}{|c|}{$(n=180)$} \\
\hline S. No. & Suggestions & Number* & Per cent & Rank \\
\hline 1. & $\begin{array}{l}\text { Providing organic certification through single } \\
\text { window system }\end{array}$ & 106 & 58.89 & VII \\
\hline 2. & $\begin{array}{l}\text { Reduce certification and renewal fee of organic } \\
\text { certification }\end{array}$ & 78 & 43.34 & XIII \\
\hline 3. & Providing organic inputs at subsidized rates & 114 & 63.34 & $\mathrm{~V}$ \\
\hline 4. & $\begin{array}{l}\text { Direct procurement of organic produce by } \\
\text { government and supply to Mid day Meals Scheme } \\
\text { (MMS) and Public distribution system (PDS) }\end{array}$ & 135 & 75.00 & III \\
\hline 5. & $\begin{array}{l}\text { Strengthen technical advisory through extension } \\
\text { services }\end{array}$ & 102 & 56.67 & VIII \\
\hline 6. & $\begin{array}{l}\text { Facilitate in creating more number of organic } \\
\text { related FPC/FPO/FIG/CIG }\end{array}$ & 95 & 52.78 & XI \\
\hline 7. & $\begin{array}{l}\text { Providing minimum support price for organic } \\
\text { produces }\end{array}$ & 122 & 67.78 & IV \\
\hline 8. & $\begin{array}{l}\text { Control fake organic produce/ products in market } \\
\text { through appropriate monitoring mechanism }\end{array}$ & 72 & 40.00 & XIV \\
\hline 9. & $\begin{array}{l}\text { Provide periodical training on organic inputs } \\
\text { preparation and value addition }\end{array}$ & 99 & 55.00 & IX \\
\hline 10. & Initiate organic farming education from school level & 60 & 33.34 & XVI \\
\hline 11. & $\begin{array}{l}\text { Ensuring timely availability and adequate quantity } \\
\text { of organic inputs }\end{array}$ & 142 & 78.89 & I \\
\hline 12. & $\begin{array}{l}\text { Creating awareness on organic farming and its } \\
\text { produce/ products }\end{array}$ & 139 & 77.23 & II \\
\hline 13. & $\begin{array}{l}\text { Establishment of organic related processing } \\
\text { industries and value addition }\end{array}$ & 110 & 61.12 & VI \\
\hline 14. & $\begin{array}{l}\text { Seed hubs for production and sale of traditional } \\
\text { seeds }\end{array}$ & 66 & 36.67 & XV \\
\hline 15. & $\begin{array}{l}\text { Free cow distribution to organic farmers and save } \\
\text { country breed from extinction }\end{array}$ & 96 & 53.34 & $X$ \\
\hline 16. & $\begin{array}{l}\text { Restoration of water bodies through government } \\
\text { interventions }\end{array}$ & 82 & 45.56 & XII \\
\hline
\end{tabular}

* Multiple responses 
High risk and uncertainty of return $(38.34 \%)$ was identified as the seventeenth major constraint by the certified organic farmers based on the rank. This might be due to the fact that high prevalence of pests and diseases, higher incidence of weeds, low price for some produce and high input cost which in turn drastically reduces the yield. During conversion period of conventional to organic farming, the crop yield was found to be reduced because of the non-application of chemical inputs. It continued until the natural soil tilth and fertility were sufficiently restored. After the transition period, the yield may stabilize at a comparably, lower or even high level as compared to conventional farming. So, the government should assist the farmers during initial three years of conversion process by providing financial assistance to the farmers, practicing organic farming.

No labeling / Standards for organic inputs (36.67\%) was identified as the eighteenth major constraint by the certified organic farmers based on the rank. Complicated methods for production of organic inputs $(33.34 \%)$ were identified as the nineteenth major constraint by the certified organic farmers based on the rank. This might be due to the inadequate availability of organic inputs in time and bulk requirement of organic inputs. Moreover, the production of organic inputs requires more time and labour intensive process. Inadequate transport facilities $(30.00 \%)$ were identified as the twentieth major constraint by the certified organic farmers based on the rank.

\section{Suggestions to enhancing adoption of organic farming practice}

Deep scan from table 3, 78.89 per cent of the certified organic farmers suggested ensuring timely availability and adequate quantity of organic inputs followed by creating awareness on organic farming and its produce/ products $(77.23 \%)$, direct procurement of organic produce by government and supply to Mid day Meals Scheme and Public distribution system $(75.00 \%)$, providing minimum support price for organic produces $(67.78 \%)$, Providing organic inputs at subsidized rates $(63.34 \%)$, establishment of organic related processing industries and value addition (61.12 \%), providing organic certification through single window system (58.89\%), strengthen technical advisory through extension services $(56.67 \%)$, provide periodical training on organic inputs preparation and value addition (55. $00 \%$ ), free cow distribution to organic farmers and save country breed from extinction $(53.34 \%)$, facilitate in creating more number of organic related Farmers Producer Company/Farmer Producer Organization/Farmers Interest Groups/Commodity Interest Groups (52.78 $\%$ ), restoration of water bodies through government interventions (45.56\%), reduce certification and renewal fee of organic certification (43.34\%), control fake organic produce/ products in market through appropriate monitoring mechanism $(40.00 \%)$, seed hubs for production and sale of traditional seeds $(36.67 \%)$ and initiate organic farming education from school level $(33.34 \%)$.

In conclusion, the major constraints are overcome by introducing appropriate interventions through state departments and other line departments. Sensitizing the policy makers and officials of state department of agriculture about the adoption of organic farming practices in study area. The extension services to be strengthened as an important source of information on organic farming practices as well as sustainable organic cultivation practices, market information and knowledge about ongoing organic farming related government schemes. The analyses of micro-level practices available to organic 
farmers in Tamil Nadu for adapting to organic farming suggest several different policy options, including the development of new drought-resistant varieties, improved weather forecasts and provision of organic marketing.

\section{References}

APEDA. 2010. National Programme for Organic Production (NPOP). Available at

http://apeda.gov.in/apedawebsite/organi c/Organic_Products.htm

Jaganathan, D., Ram Bahal and Padaria, R.N. 2009. Comparative Analysis of Profile Characteristics of Organic and Inorganic Farmers. Pusa Agri. Sci., 32: 83-86.

Muttalageri, M. and Mokshapathy, S. 2015. Constraints in Production and Marketing of Organic Vegetable Growers in Belagavi District of
Karnataka. Asian J. Management Res., 5(4).

Ranganatha, A.D., Veerabhadriah, V and Lalitha, K.C. 2001. Adoption of Organic Farming Practices by Small Farmers. Agri. Extension Rev., 13(6): 36.

Stockdale, E.A., Lampkin, N.H, Hovi, M, Keatinge, R, Lennartsson, E.K. M. Maconald, S, Padel, D.W, Tattersall, F.H, Walfe M.S. and Watson, C.A. 2001. Agronomic and environmental implications of organic farming systems. Adv. In Agron., 70: 260-306.

Thiripurasundari, K. and Divya, V. 2015. Factors Determining the aAoption of Organic Farming Among the Farming Community in Tamil Nadu. Int. J. Commerce, Business and Manage., 4(2): 1039-1044.

\section{How to cite this article:}

Sivaraj, P., H. Philip, M. Chinnadurai, M. Asokhan and Sathyamoorthi, K. 2017. Constraints and Suggestions of Certified Organic Farmers in Practicing Organic Farming in Western Zone of Tamil Nadu. Int.J.Curr.Microbiol.App.Sci. 6(3): 1270-1277.

doi: https://doi.org/10.20546/ijcmas.2017.603.146 